\title{
Contraditório público e oral como garantidor de um processo penal democrático constitucional
}

\author{
Oral and public confrontation as guarantee of a democratic \\ constitutional criminal procedure
}

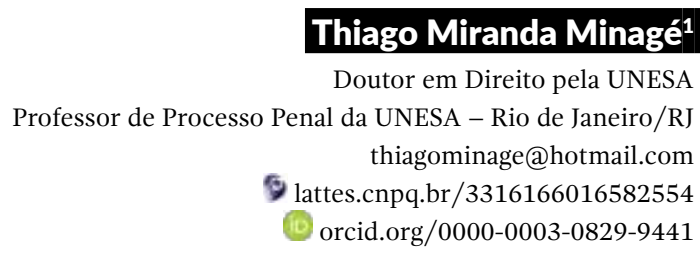

Resumo: Compreender o processo penal sob a égide de um Estado Democrático de Direito, requer, para além de uma releitura crítica de institutos já consolidados em um modelo de sistema específico, abandona-los quando os mesmos deixam de possuir legitimidade. Deve-se compreender que o papel a ser desempenhado pelas partes através do contraditório é fundamental e jamais será possível sem o amparo da oralidade e publicidade dos atos. $\mathrm{Na}$ busca de um controle da observância das garantias processuais, necessário estabelecer o contraditório como verdadeiro garantidor das garantias processuais. Para tanto, somente haverá efetividade às respectivas garantias, quando, toda e qualquer produção probatória for desenvolvida publicamente e de forma oral, mediante rito processual previamente estabelecido na lei. Para tanto, o presente trabalho começa por uma análise do sistema inquisitivo e sua permanente interferência em nosso processo penal em vigor, propondo uma superação do sistema atual, que é o acusatório, tendo em vista sua incapacidade na contenção de interferências inquisitivas, propondo uma nova visão de sistema como forma de aperfeiçoamento do então vigente, tendo como premissa a mudança do princípio unificador de forma a valorizar a oralidade e publicidade dos atos.

1 Doutor em Direito pela UNESA/RJ. Professor de Processo Penal da UNESA, ABDConst-Rio. Advogado. 
Palavras-Chave: Sistemas Processuais Penais; Contraditório; Público; Oralidade.

ABSTRACT: Understanding the criminal process under the aegis of a Democratic State of Law requires, in addition to a critical re-reading of institutes already consolidated in a specific system model, it is still necessary to abandon them when they have legitimacy. It should be understood that the role to be played by the parties through the contradictory is fundamental and will never be possible without the support of orality and publicity of the acts. In order to control the observance of procedural safeguards, it is necessary to establish the contradictory as true guarantor of procedural guarantees. In order to do so, only the respective guarantees will be effective, when, all and any probative production is developed publicly and orally, through a procedural rite previously established in the law. To this end, the present work begins with an analysis of the inquisitive system and its permanent interference in our current criminal process, proposing an overcoming of the current system, which is the accusatory, in view of its inability to contain inquisitive interference, proposing a new Vision of system as a way of perfecting what was then valid, based on the premise of a change of the unifying principle in order to enhance the oral and publicity of the acts.

KeYwords: Criminal system; Contradictory; Public; Orality.

SUMÁRIo: Introdução; 1. A Interferência do Formalismo Inquisitivo em Nosso Sistema Processual; 2. Sistema Constitucional Democrático e uma Nova Perspectiva; 3. Contraditório [desde que público e oral] como Significante Estruturante de um novo modelo de sistema processual penal; Considerações Finais; Referências.

\section{INTRODUÇÃO}

Atualmente, falar em processo com garantias ao acusado é praticamente sinônimo de impunidade aos olhos populares midiáticos, como se abreviar a trajetória processual fosse uma solução no combate à criminalidade ${ }^{2}$. Assim, contrapõem-se duas classes de pessoas: "cidadãos

2 ROXIN, Claus. Pasado, Presente y Futuro del Derecho Procesal Penal. Buenos Aires: Culzoni Editores, 2004, p. 39. 
de bem" e os "delinquentes", justificando tratamento diferenciado para os enquadrados na segunda classe com implementação de medidas mais severas e principalmente restrições de direitos no curso do processo.

Com a finalidade de obstaculizar essa draconiana concepção de processo que temos atualmente, basta que se compreenda que qualquer pessoa é um delinquente em potencial, isso não significa dizer que, necessariamente, todos se converterão em criminosos, mas que todos, um dia, pelos mais variados motivos, podem vir a sentarem-se no banco dos réus. ${ }^{3}$ Daí identifica-se e até mesmo se justifica a necessidade da forma de tratamento processual deva ser indiscriminada como se todos fossem inocentes.

O direito processual penal, assim como todos os ramos do direito brasileiro, está sob a luz das normas insculpidas na Constituição Federal, que é o fundamento de validade de todo o ordenamento jurídico pátrio, que por sua vez, se compatibiliza com documentos internacionais que tenha se comprometido em seguir e respeitar. A Constituição consagra de forma descritiva um expressivo rol de direitos e garantias constitucionais do processo que exercem papel fundamental na efetivação do Estado Democrático de Direito. E dentre as garantias do processo a Constituição Federal prevê, de forma expressa, em seu artigo $5^{\circ}$, inciso LXI, as hipóteses taxativas de prisão.

Quando o tema se volta para a privação da liberdade, a prisão somente se dará, em caráter excepcional, em caso de flagrante delito ou por ordem escrita e devidamente fundamentada da autoridade judiciária competente, nas hipóteses descritas em lei (prisão preventiva e temporária), ressalvados os casos de transgressão militar ou crime propriamente militar.

3 BARATTA. Alessandro. Criminologia Crítica e Crítica ao Direito Penal. Introdução à sociologia do Direito Penal. Rio de Janeiro: Revan, 2011. De forma resumida podemos esclarecer que todos têm impulsos destinados ao desvio, mas em razão do nível de dependência e do processo de comprometimento que estabeleceram com as instituições e com as normas comportamentais, apenas alguns os efetivam. Os mais comprometidos com o contexto social, que sabem o quanto podem perder ao optar pelo delito, tendem a não seguir esses impulsos. Em oposição, os que acreditam não ter nada a perder, têm mais facilidade em ceder aos próprios impulsos. 
A prisão preventiva, cujo regramento é encontrado nos artigos 310 a 316 do Código de Processo Penal, sofreu grandes mudanças a partir da reforma realizada pela Lei 12.403/2011. Porém, mantendo a lógica da ausência de qualquer procedimento ou formalidade para pedido/decreto da segregação cautelar, a legislação em vigor permite, ainda, a prisão cautelar preventiva de ofício por parte do juiz. Nesses termos, percebe-se que a normatização da prisão cautelar acaba por evidenciar preceitos afirmados por Raffaele Garofalo ${ }^{4}$ e Enrico Ferri ${ }^{5}$, os quais consideravam a presunção de inocência algo ilógico e vazio, bem como que a prisão preventiva deveria ser obrigatória e generalizada para os crimes considerados mais graves por conta da imposição de uma presunção de culpabilidade ${ }^{6}$.

A partir da nova redação dada pela reforma processual, o artigo 310 do Código de Processo Penal passou a consagrar as alternativas legais passíveis de adoção pelo juiz, assim que receber o auto de prisão em flagrante. Logo, por ter natureza administrativa, eis que, a prisão em flagrante não expressa uma medida cautelar/excepcional, e sim, verdadeira exceção da exceção, instrumento (flagrante) do instrumento (preventiva ou temporária), ou seja, a respectiva prisão em flagrante é verdadeira medida pré-cautelar ${ }^{7}$, cuja precariedade está exposta pela possibilidade de ser adotada por particulares ou autoridade policial, e que somente está justificada pela brevidade de sua duração, não mais se prolongando no tempo, como era feito até então ${ }^{8}$.

4 Sobre isso: GAROFALO, Raffaele, CARELLI, L. Riforma Della Procedura Penale In Itali. Torino: Fratelli Bocca Editori, 1889.

5 Sobre isso: FERRI, Enrico. Princípios do Direito Criminal: o criminoso e o crime. 2. ed. Tradução: Paolo Capitanio. Campinas: Bookseller, 1998.

6 SANTOS, Bartira Macedo de Miranda. Lombroso no Direito Penal: o destino d'O Homem Delinquente e os perigos de uma ciência sem consciência. Disponível em: <http://www.publicadireito.com.br/artigos/?cod=ea6b2efbdd4255a9>. Acesso em: 01 mar. 2017.

7 LOPES Jr., Aury. O Novo Regime Jurídico da Prisão Processual, Liberdade Provisória e Medidas Cautelares Diversas. 2. ed. Rio de Janeiro: Lumen Juris, 2011, p. 36.

8 Cabe frisar que, com a implementação da audiência de custódia, além do auto de prisão em flagrante ser remetido ao juiz, o próprio preso deverá ser apresentado. 
O artigo 311 do código de processo penal assevera que a prisão preventiva pode ser decretada em qualquer fase do inquérito policial (não fazendo menção a qualquer outra espécie de investigação) ou da instrução criminal, podendo ocorrer de ofício pelo juiz (infelizmente), quando no curso do processo, houver requerimento do Ministério Público (ação penal pública), do querelante (ação penal de iniciativa provada) ou mediante representação da autoridade policial na fase de inquérito (fase pré processual).

A aplicação desta medida cautelar é, seguindo determinado entendimento, analisada em três etapas: hipóteses de cabimento (artigo 313 do CPP), pressupostos (artigo 312 do CPP, segunda parte) e fundamentos legais (artigo 312 do CPP, primeira parte) ${ }^{9}$. As hipóteses legais de cabimento constituem a primeira questão a ser observada pelo julgador e ocorrem em cinco situações distintas: nos crimes dolosos com pena máxima privativa de liberdade superior a quatro anos (artigo 313, I, do CPP); nos casos de reincidência em crime doloso (artigo 313, II, do CPP); em casos de violência doméstica e familiar, para garantir a execução das medidas protetivas de urgência (artigo 313, III, do CPP); para fins de identificação (parágrafo único do artigo 313 do CPP) e em caso de descumprimento de outras medidas cautelares (parágrafo único do artigo 312 do CPP). Caso a situação não se enquadre em nenhuma dessas hipóteses, tal medida cautelar não será cabível.

Tendo em vista que a utilização da privação da liberdade, como providência cautelar, é verdadeira regra nos processos criminais hodiernos, pouco importando os direitos inerentes à pessoa presa, bem como as garantias processuais, pode-se perceber bem a realidade do contexto jurídico-social em que se vive. Falar de providências/medidas que limitam direitos inerentes à pessoa, certamente é uma das questões mais difíceis de justificar e fundamentar, pois, em tese, tem-se um processo penal garantidor e protetor da pessoa humana, porém, com resquícios sórdidos de um passado recente autoritário e inquisidor ${ }^{10}$.

9 NICOLITT, André Luiz. Lei 12.403/2011: o novo processo penal cautelar, a prisão e as demais medidas cautelares. 2. ed. Rio de Janeiro: Elsevier, 2016.

10 SABADELL, Ana Lucia. Manual de sociologia jurídica: introdução a uma leitura externa do Direito. São Paulo: RT, 2003, p. 124. É muito comum ouvir, entre sociólogos do direito, as seguintes frases: o Estado mantém o monopólio da 
Necessário superar, não só o contexto legislativo ultrapassado, como também abandonar uma cultura retrospectiva que emerge no momento das decisões judicias ${ }^{11}$.

Nesse sentido, é preocupante o rumo autoritário da jurisprudência atual, a qual reflete uma cultura inquisitória ainda predominante no processo penal brasileiro como verdadeira autoafirmação de quem precisa se firmar como poder, carregando altíssimo grau de discricionariedade, necessitando, assim, obter maior controle e contenção, justamente por restringir direitos através do exercício do poder, como regra rotineira. Subvertendo, pois, o sentido teórico da norma e distorcendo a essência dos mandamentos constitucionais em questão.

Assim, partindo dessa premissa, amparado ainda nos ensinamentos de Alberto Binder, urge a seguinte ponderação: torna-se imperioso refletir se, todavia, é possível considerar a prisão preventiva como uma simples 'medida cautelar' quando, na realidade, está cumprindo as finalidades de uma pena de fato [definitiva $]^{12}$. A referida reflexão vem à tona justamente por motivos óbvios, pois na prática diária nos tribunais estaduais e federais e, principalmente, em primeira instância, as decisões estão sendo proferidas de forma que a prisão preventiva se tornou uma medida habitual e rotineira.

Como proposta de uma forma para o controle e contenção do uso indiscriminado da prisão preventiva o contraditório público e oral deve estruturar toda a temática processual penal.

violência legítima; o Estado é um aparelho violento ou um mecanismo de violência. Essas afirmações, que provém de Max Weber, indicam que o Estado, quer o indivíduo aceite ou não, tem a capacidade de impor a sua vontade. Weber definia o estado como um mecanismo que consegue manter o monopólio do exercício legítimo da violência física.

11 Por interpretação retrospectiva entende-se a insistência dos operadores jurídicos de "interpretar o texto novo de maneira a que ele não inove nada, mas ao revés, fique tão parecido quanto possível ao antigo”. Em outras palavras, através da interpretação retiram-se as perspectivas de transformação que vieram acertadas na nova Constituição. É, antes de tudo, uma interpretação covarde, pois prima pelo medo de rupturas (CASARA, Rubens. R.R. Interpretação Retrospectiva, Constituição e Processo Penal. Revista da EMERJ, v. 6, n. 22, 2003, p. 111).

12 BINDER, Alberto M. Introdução ao direito processual penal. Rio de Janeiro: Lúmen Juris: 2003. p. 23-32. 


\section{A Interferência do Formalismo Inquisitivo em nosso Sistema Processual}

A ideia trabalhada por Luigi Ferrajoli ${ }^{13}$ de que "nulla culpa sine judicio" possui significativa grandeza e importância para compreensão deste tópico. A obrigatoriedade do processo, no entanto, não é algo que possua valor, por si só, que permita uma explicação de forma reducionista, como por exemplo, identificando funções e suas respectivas definições ${ }^{14}$. Partindo-se dessa premissa para iniciar-se uma análise da finalidade do processo penal, tem-se desafios variantes à frente, tais como a incerteza do resultado processual e o uso desmedido do exercício do poder jurisdicional ${ }^{15}$.

Com a promulgação da Constituição da República Federativa do Brasil de 1988, percebeu-se a necessidade de adequação a alguns conteúdos jurídicos para que, necessariamente, atendessem à concepção de estado democrático de direito, principalmente quanto aos conteúdos normativos inerentes ao processo. A permanência no tratamento do processo como relação jurídica entre as partes e o juiz, colocando-o como um instrumento da jurisdição, com a finalidade de realizar os escopos metajurídicos, bem como a pacificação social, e consequente enfraquecimento das partes ${ }^{16}$ [autor e réu], demonstrou-se equivocado ${ }^{17}$. Principalmente, por permitir o malsinado solipsismo judicial, admitindo que o juiz seja o único intérprete no processo, podendo fundamentar sua decisão em argumentos metajurídicos, inclusive, alheios a preceitos

13 FERRAJOLI, Luigi. Direito e Razão: Teoria do Garantismo Penal. São Paulo: RT, 2002. p. 73-74.

14 PRADO, Geraldo. Prova Penal e sistemas de controles epistêmicos. A quebra da cadeia de custódia das provas obtidas por métodos ocultos. São Paulo: Marcial Pons, 2014, p. 18.

15 FERRAJOLI, Luigi. Direito e Razão: Teoria do Garantismo Penal. São Paulo: RT, 2002. p. 95-96.

16 NUNES, Dierle José Coelho. O princípio do contraditório. Boletim Técnico da Escola Superior de Advocacia da OAB/MG, Belo Horizonte, v.1, p. 39-55. jan./ jun. 2004. p. 43

17 STRECK. Lenio. Do pamprincipiologismo à concepção hipossuficiente de princípio. Dilemas da crise do direito. Revista de Informação Legislativa, Brasília, a. 49, n. 194, abr./jun. 2012. p. 10. 
constitucionais, sobretudo pela falta de instrumentos de contenção e controle em relação às decisões judiciais ${ }^{18}$.

A mentalidade formalista age como se fosse uma herança que se caracteriza pelo apego não necessariamente ao ritual, mas sim à rotina, ou seja, às formas superficiais que conformam a vida cotidiana dos tribunais, verdadeiros tabus ${ }^{19}$. Esse formalismo superficial forjou uma linguagem de difícil acesso, razão pela qual as pessoas sentem que sempre precisam de um advogado, não só para defendê-las, mas, sobretudo, para funcionar como tradutor daquilo que está ocorrendo perante o juízo.

Não raro perceber que, junto com o sistema inquisitivo, há uma cultura inquisitória arraigada nas sociedades latino-americanas, que tem como consequência estrutural uma mentalidade eminentemente formalista e burocrática, a qual se utiliza de uma linguagem jurídica obscura e de métodos interpretativos retrospectivos ${ }^{20}$, com práticas conservadoras e pouco criativas, ou seja, raramente advogados ou juízes propõem reformas do sistema e, quando o fazem, remetem a questões superficiais, como, por exemplo, a simples alteração de um prazo.

Ademais, para Alberto Binder e Leonel Postigo, em sendo decorrência do direito canônico, o sistema inquisitivo nunca deixou de ter certo grau de sagrado, ainda que de maneira implícita, mesmo depois de tantos anos e de tantas revoluções liberais que procuraram justamente dessacralizar vários setores da vida pública ${ }^{21}$. Conforme Binder, "de qualquer sorte, mantém-se uma espécie de religião laica acerca da administração da justiça e do papel do juiz, como se este agisse investido por um poder divino"22. Talvez isso explique o porquê do conservadorismo identificado.

18 Ibidem. p. 9.

19 FREUD, Sigmund. Totem e Tabu. Algumas correspondências entre a vida psíquica dos selvagens e a dos neuróticos. Tradução do alemão de Renato Zwick. Porto Alegre: L\&PM POCKET, 2013, p. 39.

20 CASARA, Rubens. R.R. Interpretação Retrospectiva, Constituição e Processo Penal. Revista da EMERJ, v. 6, n. 22, 2003, p. 192-222.

21 UNODC/CEJA (2013). La reforma procesal penal en Latinoamérica. In: Evalución de la implementación del sistema penal acusatório en Panamá, p. 0712. Disponível em: <http://biblioteca.cejamericas.org/handle/2015/5493>. Acesso em: 07 dez. 2016. p. 7-8.

22 BINDER, Alberto M. Introdução ao direito processual penal. Rio de Janeiro: Lúmen Juris: 2003. p. 200-202. Esta sacralidade de todo o sistema judicial, 
Superar a dicotomia acusatório versus inquisitório, de fato, permite compreender as atuais estruturas processuais culturalmente impostas em países da América Latina, inclusive, e, principalmente, no Brasil, pois, como identifica Alberto Binder, os latino-americanos conservam de uma maneira ou de outra o velho sistema inquisitório, fruto, especialmente, das colonizações europeias monárquicas, mesmo tendo se passado mais de cinco séculos de aplicação, chegando a ser mais do que um sistema processual ${ }^{23}$ : é um sistema completo de administração da justiça penal ${ }^{24}$.

Para isso, torna-se fundamental deslocar o "problema" de onde está sendo debatida a estrutura processual para se determinar uma questão externa de mudança de premissa e compreensão de suas vertentes, de forma a desvelar e permitir reflexões, até então, omitidas ${ }^{25}$.

Isto é, trava-se intenso debate quanto às características e consequências, mas não se ataca o cerne do problema, qual seja a origem constitutiva do sistema processual. Isso mantém o debate nas mesmas condições estabelecidas e consolidadas as quais consagraram um sistema inquisitivo, com interferências acusatórias ou acusatório com inserções inquisitivas ${ }^{26}$. Nesse panorama, manter a argumentação crítica, partindo dos mesmos pressupostos constitutivos, esbarra em uma circularidade impeditiva do deslocamento do problema para fora das premissas impostas e, consequente, estabilização do tema, tal qual uma

particularmente do sistema penal, e a consequente função quase sacerdotal que os juízes, às vezes, crêem ter também presente em alguns tratados de ética da profissão de advogado confere uma rigidez ao sistema que o faz ser pouco inclinado a adotar soluções modernas para superar seu estado de crise, controlar a sobrecarga de trabalho, como o princípio da oportunidade, a probation ou outras tantas saídas alternativas do sistema.

23 Essa é a questão. O sistema misto não é permitido ou possível, ou seja, tem que extirpar do direito o ranço inquisitório. Mas, para isso, deve-se responder a uma pergunta: $\mathrm{O}$ direito faz a sociedade ou a sociedade faz o direito? Respondendo: ambos, o direito é deontológico.

24 BINDER, Alberto M. Introdução ao direito processual penal. Rio de Janeiro: Lúmen Juris: 2003. p. 200-204.

25 PRADO; Geraldo; CASTANHO DE CARVALHO, L. G Grandinetti; MARTINS, Rui Cunha. Decisão Judicial. A cultura jurídica brasileira na transição para a democracia. São Paulo: Marcial Pons, 2012. p. 72.

26 Ibid., p. 71. 
armadilha, cujo efeito é a manutenção do debate dentro de um âmbito "seguro", no qual as respostas retóricas/justificativas prevalecem, em detrimento das proposições críticas levantadas. Talvez, por isso, a insistente falta de solução aos debates e a manutenção do status quo da irregularidade, sejam ocasionadas pela maniqueísta divisão inquisitivo versus acusatório.

Para se entender o tema proposto e, principalmente, sua lógica sistemática, deve-se partir da compreensão do processo como um dispositivo articulador de elementos de várias ordens, cujas modalidades de interação possuem como características indissociáveis: a regularidade procedimental ${ }^{27}$ e imprevisibilidade de resultado. É necessário, para tanto, a construção de um sistema processual que corresponda à vontade de impor uma estrutura dotada de significado e que refute a distorção de sentido dos elementos processuais ${ }^{28}$. Por isso, a importância das bases garantistas como controle epistemológico na contenção do exercício arbitrário do poder.

A interferência de sistemas, anteriormente mencionada, deve ser combatida para se alcançar uma unidade estrutural, que parta de um ponto fundante e se exteriorize pela definição do princípio unificador. É importante identificar o princípio unificador que atua como verdadeiro referente ordenador ${ }^{29}$ (o princípio é mais do que o próprio modelo, é uma tradução orgânica do sistema processual a ser adotado ${ }^{30}$ ), ou, ainda, identificar os elementos ordenadores que são aqueles que, se houver a alteração de um, haverá a modificação de todos, tendo em vista pertencerem ao mesmo modelo e grupo de transformações ${ }^{31}$.

27 FERRAJOLI, Luigi. Direito e Razão: Teoria do Garantismo Penal. São Paulo: RT, 2002. p. 95-96.

28 PRADO; Geraldo; CASTANHO DE CARVALHO, L. G Grandinetti; MARTINS, Rui Cunha. Decisão Judicial. A cultura jurídica brasileira na transição para a democracia. São Paulo: Marcial Pons, 2012. p. 73.

29 MIRANDA COUTINHO, Jacinto Nelson de. As reformas parciais do CPP e a Gestão da Prova: Segue o Principio Inquisitivo, Boletim do IBCCRIM, ano 16, no 188 , p. 11-13.

30 Ibid., p. 12.

31 LÉVI-STRAUSS, Claude. Antropologia Estrutural Dois. $4^{\text {a }}$ ed. Rio de Janeiro: Tempo Brasileiro, 1993. p. 69. 
Com esse jaez, a necessidade de um sistema coeso corresponde à importância de impor uma estrutura dotada de sentido, que refute distorções constitutivas de elementos processuais, direcionando a efetivação da finalidade processual penal. Assim, se constituirá uma estabilidade procedimental ordenada ${ }^{32}$, partindo da eleição de um determinado elemento fundante do processo para, então, consequentemente, redistribuir os lugares e desempenhos no desenvolvimento processual. Um verdadeiro deslocamento de base estruturante que afeta diretamente todo o desenvolvimento do processo.

Críticas surgem, com razão, quanto aos conceitos de sistemas estagnados nessa dicotomia. Por exemplo, Juan Montero Aroca ${ }^{33}$ deixa claro sua inquietude a esses conceitos, alegando tratar-se de questões ultrapassadas, sem valor, de pouca clareza, confundindo mais do que explicando toda a engrenagem processual. Portanto, por conta das transformações jurisdicional e constitucional, é preciso realinhar o ponto de partida da compreensão, justamente para evitar leituras descontextualizadas do âmbito empírico. Manter-se preso à noção histórica, conduz ao abismo da escuridão, impedindo, assim, uma leitura constitucionalizada do processo. Surge, então, a necessidade por uma leitura acurada dos documentos de direitos humanos e da própria Constituição da República.

Até mesmo a (re)leitura da Constituição deve aflorar. Basta uma análise superficial para identificar não se tratar de um documento coeso, fruto de uma parcela da coletividade pensante. Vários fatores influenciaram em sua redação final: fatores políticos, sociais e, principalmente, econômicos, daquela época (1987-1988) ${ }^{34}$. Em um Estado

32 FERRAJOLI, Luigi. Direito e Razão: Teoria do Garantismo Penal. São Paulo: RT, 2002. p. 95-96.

33 AROCA, Juan Montero. El derecho procesal en el Siglo XX. Valencia: Tirant lo Blanch, 1997, p. 106. Basicamente o autor critica as concepções de sistema inquisitivo por haver contradição terminológica entre sistema processual inquisitivo e processo, alegando que processo pressupõe a aplicação das garantias processuais. Quanto ao sistema acusatório que se concebe um juiz como sujeito passivo rigidamente separado das partes, e um processo como uma contenda entre iguais, iniciada por uma acusação, sobre a qual recaia a carga da prova, entretanto, em ambos os sistemas, carecem de definições e concretizações de seus preceitos, logo, falhos desde a origem constitutiva.

34 PILATTI, Adriano. A Constituinte de 1987-1988. Progressistas, Conservadores, Ordem Econômica e Regras do Jogo. Rio de Janeiro: Lúmen juris, 2008. p. 35-39. 
Democrático de Direito, os valores constitucionais devem ser e estar compatíveis em todo o atuar estatal, principalmente, aqui no jurisdicional $^{35}$. O processo criminal deve expressar os direitos e servir como garantia de tantos outros direitos constitucionais, sob pena de que, se assim não o for violará a própria ordem do Estado de Direito.

O garantismo representa uma virada de paradigma que fundamenta a democracia constitucional, assim, o modelo normativo jurídico que visa à efetivação dos direitos fundamentais cuja extensão comporta: da vida à liberdade pessoal, da liberdade civil e política às expectativas sociais de subsistência, dos direitos individuais àqueles coletivos ${ }^{36}$.

O paradigma garantista, ao qual aqui se vincula a democracia constitucional, tem uma visão fundamental: a autonomia do direito. Essa autonomia vem proposta por uma edificação complexa, criada em cima de um modelo integrado de ciência jurídica, que comporta a teoria do direito, a dogmática jurídica, a filosofia da justiça e a sociologia do direito. Esse entrelaçamento provoca uma relação dialógica (contraditório) entre efetividade (oralidade ${ }^{37}$ ) e legitimidade (publicidade) ${ }^{38}$, em que a garantia funciona como sinopse, tanto à compreensão do grau de efetividade do direito, em relação aos seus próprios níveis normativos,

35 "Quanto à igualdade de poderes, é claro que ela supõe que a acusação pública esteja despojada de poder sobre o imputado, sendo todos os poderes de uma parte sobre a outra 'letais às liberdades civis', mas exigiria também [...] a defesa pública de um magistrado, apoiada pela defesa profissional do defensor privado [...]" (FERRAJOLI, Luigi. Direito e Razão: Teoria do Garantismo Penal. São Paulo: RT, 2002. p. 491).

36 NETO, Alfredo Copetti. A Democracia Constitucional sob o olhar do garantismo jurídico. Florianópolis: Empório do Direito, 2016. p. 23.

37 Um debate impõe que as partes estejam presentes e atuantes na contribuição para construção do ato decisório a ser proferido. Impedindo assim, por exemplo, invenções como o contraditório diferido que torna completamente ineficaz o contraditório. Talvez, ao menos até então, a oralidade foi a maneira mais eficaz que nossa cultura encontrou para dar vigência aos princípios políticos aqui trabalhados.

38 Os atos decisórios para serem legítimos devem ser de conhecimento prévio das partes envolvidas e afetadas, ou seja, respeitar o contraditório, que é efetivado pela sua prática oral, permite o acesso dos envolvidos a todo conteúdo, contrapondo o sigilo místico do sistema inquisitivo. Sem contar que, a publicidade do julgamento significa que as decisões são transparentes, que cumprem com o principio republicano da transparência dos atos praticados. 
como, também, ao grau de legitimidade desses mesmos níveis normativos $^{39}$. Por isso, a necessidade de compreensão de como é, para então propor, como deve ser.

Um sistema processual, nada mais é que um complexo de relações que atuam como verdadeiros círculos concêntricos, onde o de maior diâmetro envolve o de menor, ou seja, parte-se de um sistema político que envolve o sistema constitucional que, por sua vez, envolve o sistema judiciário e, por fim, envolve o sistema processual, o qual, nas palavras de Rui Cunha Martins, é o verdadeiro microcosmo democrático do estado de direito ${ }^{40}$. Um processo que possa minimamente ser considerado justo não se funda apenas em garantias particulares e, sim, na coordenação de várias garantias concorrentes e articuladas, formando uma circularidade, que deflagra uma conectividade recíproca, conferindo efetividade umas às outras, de forma sucessiva ${ }^{41}$.

Ao identificar as bases estruturais do sistema processual na própria Constituição conjugada com os documentos internacionais, compatibiliza-se o Estado de Direito com o Estado Democrático, de uma forma que, partindo de um macro sistema e, consequentes, microssistemas englobados uns pelos outros, reduzir-se-ia de forma considerável ou, até mesmo, impossibilitaria a interferência de características de um sistema, em detrimento do outro. Isso se daria não como forma de negar a existência de processos penais anteriores à Constituição ou ao próprio Estado de Direito, mas apenas no sentido de deslocar a compreensão de processo para uma realidade político-jurídico-social.

Eis, por conseguinte, a vital importância do princípio unificador ${ }^{42}$ em uma lógica sistêmica/circular, em cujo bojo todo o sistema processu-

39 STRECK. Lenio. Do pamprincipiologismo à concepção hipossuficiente de princípio. Dilemas da crise do direito. Revista de Informação Legislativa, Brasília, a. 49 n. 194 abr./jun. 2012, p. 18-19.

40 MARTINS, Rui Cunha. O Ponto Cego do Direito. Rio de Janeiro: Lúmen Juris, 2010, p. 92.

41 Ibid., p. 92.

42 A importância sistémica do "princípio unificador" é, pois, irrecusável. Tanto que "só se muda o sistema caso se mude o princípio unificador". Sobre o tema, ver: MIRANDA COUTINHO, Jacinto Nelson de. Introdução aos princípios gerais do processo penal brasileiro. Revista da Faculdade de Direito da UFPR, a. 30, n. 30, 1998. 
al existe frente a uma tensão da dinâmica processual pela conectividade dos atos e a busca pela eleição de um referente ordenador, que para ser reconhecido deve ser parte constitutiva do sistema processual ${ }^{43}$. Tanto que o critério de admissibilidade desse referente ordenador é o contraditório -, como dito anteriormente, o processo possui o contraditório como elemento definidor de sua estrutura, exigindo que os interessados e os contra interessados (partes do processo), que suportarão o resultado favorável ou desfavorável da decisão, possam participar em igualdade de condições do iter procedimental, para a formação da decisão ${ }^{44}$.

Essencial entender que o processo penal deve ser compreendido como um instrumento político de participação, que de acordo com o nível de democratização social atuará com maior ou menor intensidade, tendo a Constituição da República de 1988 como limite às insurgências autoritárias no processo e, ainda, a considera caminho necessário para uma efetiva conexão entre direito, processo e democracia ${ }^{45}$.

Observa-se que é em face da democracia substancial que se assentam as características constitucionais determinantes à ilegitimidade de poderes desregulados e, consequente uso arbitrário do poder, nesse contraponto, também, a legitimidade da subordinação desses ao direito, cujo reconhecimento, como direito válido, decorre unicamente do seu condicionamento às escolhas constitucionais, as quais estabelecem, além das formas para a sua produção, os conteúdos a serem produzidos. Isso representa, por um lado, a expansão do caráter normativo do direito, tanto na sua relação com a política (democracia política), como na sua relação com a economia (democracia civil), por outro, indubitavelmente, qualifica, sobretudo, a própria emancipação e autonomia do direito de qualquer vontade majoritária, como também de qualquer determinação econômica ${ }^{46}$.

43 MARTINS, Rui Cunha. O Ponto Cego do Direito. Rio de Janeiro: Lúmen Juris, 2010, p. 93.

44 FAZZALARI, Elio. Istituzioni di diritto processuale. Padova: Cedam, 1992, p. 86-862; ROSA, Alexandre Morais da. Guia Compacto do Processo Penal Conforme a teoria dos jogos. 3. ed. Florianópolis: Empório do Direito, 2016, p. 147-156. ROSA, 2014, p. 5-26.

45 Sobre isso, ver: ROSA, Alexandre Morais da. Decisão Penal. A bricolage de significantes. Rio de Janeiro: Lúmen Juris, 2006.

46 FERRAJOLI, Luigi. Principia Iuris. Teoria del diritto e della democrazia. 2. Teoria della democrazia. Roma-Bari: Laterza, 2007, p. 426. 
Na concepção do garantismo jurídico, a democracia constitucional tem de ser vista, compreendida e elaborada dentro do desenho do Estado Constitucional, isto é, funcionando como um contrapoder aos poderes públicos e privados e, como uma composição essencial a todas as dimensões da democracia, sejam elas de conteúdo ou de forma, desde que rompa com a concepção de poder altamente discricionário da administração, colocando-o sob a aresta de função de garantia, isto é, como um dever positivo absoluto, desfazendo, com isso, a falácia criada pela suposta tensão entre estado social e estado de direito ${ }^{47}$.

Noutras palavras, é dizer que a teoria do direito é a necessária premissa da teoria da democracia. Ou seja, no garantismo jurídico, democracia é, antes de tudo, um sistema de regras e garantias impostas aos diversos tipos de poder, por isso que, por um lado, se encontra empiricamente ancorada à experiência histórica do constitucionalismo democrático; por outro, aos limites e aos vínculos de direito positivo, por esse imposto ${ }^{48}$.

Neste momento, importante destacar a necessidade de construção de uma problemática, com base no pensar de assuntos que o senso prático comum coloca. É no Estado Democrático de Direito que o devido processo legal não tem que ter uma vinculação ao estrato social da pessoa que está a ser julgada ${ }^{49}$.

O povo é identificado como portador de um desígnio sacrossanto. Ele não se engana, é sabedor. Essa é uma retórica que permeia a narrativa dos consensos democráticos, de que a bondade está no povo, uma verdadeira linguagem da revolução francesa que alimenta uma suspeição quanto à política e, acaba por omitir que o povo, como massa, foi conivente com a ditadura e com o totalitarismo. Por isso, não é de se espantar que, atualmente, determinados cidadãos não queiram garantias processuais, sob alegação, de ser um exagero protetivo ${ }^{50}$.

47 NETO, Alfredo Copetti. A Democracia Constitucional sob o olhar do garantismo jurídico. Florianópolis: Empório do Direito, 2016. p. 117.

48 NETO, Alfredo Copetti. A Democracia Constitucional sob o olhar do garantismo jurídico. Florianópolis: Empório do Direito, 2016. p. 25.

49 MARTINS, Rui Cunha. O Ponto Cego do Direito. Rio de Janeiro: Lúmen Juris, 2010, p. 92.

50 NETO, Alfredo Copetti. A Democracia Constitucional sob o olhar do garantismo jurídico. Florianópolis: Empório do Direito, 2016. p. 25. 
O Estado de Direito tem dificuldade de lidar com a massa, que é produto de um compromisso de várias forças conservadoras, que devem se garantir também contra o povo. A própria rua não percebe que o discurso do Estado de Direito existe para proteger, que as garantias são para todos os indivíduos, ou seja, não se tem essa ideia, não se sente isso como seu ${ }^{51}$.

Hoje se vive em um mundo que apresenta problemas novos, para os quais só existem mecanismos antigos. Quando se vive em ditaduras, a ruptura é tentar o ato revolucionário, pois as sociedades que passaram da ditadura para a democracia, usaram o mecanismo da transição, que é incompleto. Transita-se, mas há muito que permanece, por exemplo, as leis em vigor no período ditatorial não são todas alteradas em um momento de transição política. Ela diz que alguma coisa, a partir de agora, se pode fazer, mas está tudo por fazer ${ }^{52}$.

Não é possível se deixar seduzir pela ideia de que a democracia é unicamente governo do povo, como se fosse um corpo coletivo coerente e possuidor de vontade homogênea. Desse modo, uma redefinição da soberania popular redireciona o elo entre democracia e povo, o que, por conseguinte, estabelece que as decisões da maioria, como vontade do povo, não são suficientes, embora necessárias, à definição de democracia ${ }^{53}$.

51 CATtONi DE OLIVEIRA, M. A. Comentário ao Art. $1 .^{\circ}$, parágrafo único. In: CANOTILHO, J. J. G.; MENDES, G. F.; SARLET, I. W.; STRECK, L. L. (coord.). Comentários à Constituição do Brasil. São Paulo: Saraiva, 2013, p. 137-140. A ideia extraída dos escritos do autor se refere à parte onde o mesmo afirma: "Se todo poder emana do povo que o exerce diretamente ou por meio de seus representantes eleitos (Cf. Art. $1 .^{\circ}$, parágrafo único, da Constituição Brasileira), o princípio da democracia constitucional envolve a defesa de um patriotismo constitucional que visa compreender a própria Constituição do Estado Democrático de Direito como processo de aprendizagem social por parte do povo como instância política plural, contra toda a velha teologia política do macrossujeito povo como nação soberana, una e indivisível ou do povo como mero ícone ou instância de legitimação (Müller).”

52 Sobre isso, ver: CHOUKR, Fauzi. H. Transição e Consolidação da Democracia. Florianópolis: Empório do Direito, 2016.

53 NETO, Alfredo Copetti. A Democracia Constitucional sob o olhar do garantismo jurídico. Florianópolis: Empório do Direito, 2016. p. 24-26 
Isso quer dizer que um sistema, para que possa ser democrático, deve limitar e vincular todos os poderes, inclusive o poder da maioria, enquanto soberania popular, que forma a democracia, na qual os direitos fundamentais estabelecem vínculos substanciais, contrapondo-se à ideia que determina a democracia como um método, garantido, evidentemente, pelo sufrágio universal e pelo princípio da maioria. ${ }^{54}$

Todo pronunciamento judicial deve possuir legitimidade política onde a estabilidade procedimental tem como amparo garantias processuais que decorrem da nullum iudicium sine accusatione, sine probatione et sine defensione. Aqui se fala da estrita submissão do processo penal à jurisdição, que deve viabilizar as condições estruturais sobre quem pode, como se deve, o que se deve ou não decidir, referindo-se às formas de governo e estrutura dos poderes, que dependerão diretamente do caráter politicamente democrático ou não do sistema político e, portanto, do caráter de direito do sistema jurídico.

De forma acurada Ferrajoli detecta que na Constituição encontram-se normas que caracterizam a formação de Estado, como democrático, e, também, como Estado de Direito, ao estabelecer procedimentos (Estado Democrático) e direitos fundamentais individuais (Estado de Direito). No entanto, ao se deparar, de forma frequente, com violações de normas procedimentais inerentes ao Estado Democrático, que deveria ensejar constatação imediata de inexistência do ato por afetação na origem, permanece-se convivendo, mediante explicações retóricas e justificativas descabidas, por se manter/insistir o debate no interior dicotômico processual de sistema acusatório e inquisitivo ${ }^{55}$. Necessário um sistema que proteja os direitos e garantias constitucionais.

54 CATTONI DE OLIVEIRA, M. A. Comentário ao Art. 1. ${ }^{\circ}$, parágrafo único. In: CANOTILHO, J. J. G.; MENDES, G. F.; SARLET, I. W.; STRECK, L. L. (coord.) Comentários à Constituição do Brasil. São Paulo: Saraiva, 2013, p. 137-140.

55 "Pode-se acrescentar que frequentemente a violação das regras do primeiro tipo é causa de inexistência ou não-vigor, enquanto aquela das regras do segundo tipo é causa de invalidade das normas produzidas; e que a característica estrutural do Estado de direito ao mero Estado legal é a possível divergência entre validade e vigor, ou seja, a existência de normas vigentes mas inválidas porque conformes às regras do primeiro tipo e desconformes às do segundo" (FERRAJOLI, Luigi. Direito e Razão: Teoria do Garantismo Penal. São Paulo: RT, 2002. p. 688-689). 


\section{Sistema Constitucional Democrático e uma Nova Perspectiva}

O sistema penal é na práxis forense e na teoria, cada dia mais, o resultado da tensão entre o exercício (e suas facilitações) do poder de punir e seus limites (ou falta) concretos. De um lado encontram-se não apenas medidas legislativas que aumentam a potencialidade das punições, seja com a expansão das condutas criminalizadas, ou com o recrudescimento das penas cominadas aos tipos penais já existentes, como, também, a criação de medidas processuais que reduzem o espectro de garantias, com a invasão da privacidade e violação dos direitos individuais das pessoas submetidas à investigação ou ao processo criminal ${ }^{56}$.

A ideia e os ideais de constitucionalismo democrático passaram por alterações no decorrer dos tempos, tornando-se (junto com os tratados internacionais) o mais importante instrumento jurídico constitutivo de direitos e garantias, na proteção de liberdades e na imposição de limites ao exercício do poder dos órgãos constituídos e do próprio povo, contrapondo-se ao dito popular de que se vive o governo da maioria ${ }^{57}$. Assim, o garantismo jurídico, mediante suas manifestações, assumindo uma posição crítica a respeito do direito, põe em questão qualquer proposta teórica que se mostre desvinculada de um controle empírico; bem como qualquer posição prática que se mostre apartada de princípios teóricos na proteção da liberdade individual, contra qualquer forma de exercício arbitrário de poder.

Partindo de um conceito, mesmo que no plano lógico-formal, de que uma norma consiste em um cânone de valoração de uma conduta, que estabelece a descrição de um comportamento, seus elementos e requisitos, qualificando de lícito e devido, e, por consequência, uma conduta ilícita seria estabelecida pelo comportamento contrário ao determinado na norma ${ }^{58}$, os princípios ganham, assim, importante posição

56 SANTORO, Antônio Eduardo Ramires; RANGEL. Natália Ribeiro. O Princípio Constitucional do Contraditório na Interceptação das Comunicações Telefônicas. In: MENDES, Soraia da Rosa LONGO, Ana Carolina F. Segurança Pública. Brasília: IDP, 2015. p. 7-34.

57 FERRAJOLI, Luigi. Direito e Razão: Teoria do Garantismo Penal. São Paulo: RT, 2002. p. 894.

58 FAZZALARI, Elio. Istituzioni di diritto processuale. Padova: Cedam, 1992. p. 45. 
constitutiva e limitativa, instituindo direitos humanos e fundamentais, que, uma vez constitucionalizados, passariam a ser norteadores de todo o ordenamento jurídico, ou seja, os princípios seriam o marco da institucionalização da autonomia do Direito.

As regras não acontecem sem os princípios, logo, os princípios sempre atuam como determinantes para concretização do Direito e, em todo caso concreto, eles devem conduzir para a determinação da resposta adequada ${ }^{59}$. Contudo, para que tenham real eficácia, passando a ideia de efetividade e eficiência, dependem de sua concretização pelos poderes constituídos, mesmo que seja mediante uma forma de controle empírico (processo criminal) ${ }^{60}$.

Em países de modernidade tardia, como é o caso do Brasil, muitos dos direitos e garantias constitucionais não têm sido efetivados na prática, restando premente a intervenção do poder judiciário que, por sua vez, acaba por não efetivar outros direitos e garantias, inerentes à proteção individual do investigado ou acusado, justamente por falta de limites impostos à sua atuação no exercício do poder ${ }^{61}$. É nesse momento que o processo passa [ou deveria] a figurar como importantíssima ferramenta que compreende esse olhar constitucional como instrumento de efetivação das garantias individuais.

Falar em democracia constitucional é admitir que em hipótese alguma haverá contexto democrático fora da Constituição ${ }^{62}$. Desse modo, não há que se falar em direitos que pertençam à maioria ou minoria, mas, indiscriminadamente, a todos e a qualquer um, os quais compõem, também, o poder do povo e, sob esse aspecto, obviamente, também fazem parte da democracia ${ }^{63}$, pondo-se em construção conti-

59 Sobre isso, ver: STRECK, Lenio Luiz. Do pamprincipiologismo à concepção hipossuficiente de princípio. Dilemas da crise do direito. Revista de Informação Legislativa, Brasília, a. 49 n. 194, abr./jun. 2012.

60 FERRAJOLI, Luigi. Direito e Razão: Teoria do Garantismo Penal. São Paulo: RT, 2002. p. 894.

61 Ibidem, idem.

62 ADEODATO, João Maurício. Jurisdição constitucional à brasileira - situações e limites. Revista do Instituto de Hermenêutica Jurídica, Porto Alegre, v.1. n.2, 2004. p. 176.

63 NETO, Alfredo Copetti. A Democracia Constitucional sob o olhar do garantismo jurídico. Florianópolis: Empório do Direito, 2016. p. 51-52. 
nuada pela comunidade jurídica, tendo como premissa os direitos fundamentais conquistados e descritos, uma vez que não é um projeto congenitamente acabado, mas uma proposição suscetível de revisibilidade constante $^{64}$, para ampliação e efetivação desses direitos, o que propicia um caráter modificador e concretizador das garantias fundamentais.

Assim, deve-se entender o processo como uma garantia e, não como um entrave na proteção e (re) afirmação de direitos, logo, esse é o principal motivo que leva a entender que os direitos e garantias constitucionais devem ser os pressupostos de um processo democrático, em que ele passa a ser um meio de fixação político-jurídica das dimensões formais e materiais dos direitos humanos fundamentais, nas quais as garantias processuais servem como principal instrumento de contrapoder, com a efetiva proteção daqueles direitos, assim concretizando, reforçando e protegendo a sua aplicabilidade.

Os direitos fundamentais consagrados na Constituição estabelecem situações subjetivas instrumentais, cuja previsão constitucional não teria nenhum significado se as correspondentes garantias (em especial no âmbito processual) não permitissem restaurá-las integralmente, quando violados e, principalmente, mediante limitação do exercício do poder no caso concreto. O próprio conceito de inviolabilidade dos direitos fundamentais se exauriria numa estéril abstração, se a possibilidade de violação não correspondesse à possibilidade de tutela da situação subjetiva violada, em especial, o direito individual de um investigado ou acusado ${ }^{65}$.

Para tanto, o processo precisa harmonizar seus conceitos à realidade constitucional, o que só será possível quando submeter, integralmente, o processo (penal) à Constituição, deixando o processo de ser um mero instrumento para contendas individualizadas e possa vir a se transformar em um efetivo garantidor de direitos ${ }^{66}$. A reflexão acerca do processo e constituição far-se-á através da ideia de que as normas

${ }^{64}$ LEAL, Rosemiro Pereira. Teoria Processual da Decisão Jurídica. São Paulo: Landy, 2002, p. 31.

${ }^{65}$ CUNHA JUNIOR, Dirley da. Curso de Direito Constitucional. 2. ed. Salvador: JUSPODIVM, 2008, p. 661.

${ }_{66}$ BINDER, Alberto M. Análisis político criminal: bases metodológicas para una política criminal minimalista y democrática. Buenos Aires: Astrea, 2011. p. 32. 
(ordenamento jurídico) processuais serão consequência de uma dimensão deontológica própria do direito, uma vez que se articula a partir de princípios para consecução das regras (leis).

Dessa forma é necessária uma ruptura com aquela autonomia formal legislativa, principalmente quando contrariam direitos fundamentais e demais compromissos com a sociedade democrática. Os princípios, nesse sentido, são o modo pelo qual toda essa normatividade adquire força normativa para além das suficiências das regras, visto que são os princípios que instituem as bases para a normatividade do direito.

Assim, os estudos constitucionais do processo têm possibilitado descortinar novos horizontes para a ciência processual, propiciando novas implicações sociais e políticas do sistema ${ }^{67}$. Diante da complexidade social, em especial, em países como o Brasil, o retorno de valores ao direito inspira cuidados especiais, fato este que demonstra a importância de compreender o efetivo papel dos princípios, quando da constituição do ordenamento jurídico pátrio, lembrando sempre de ser ele o instituidor da regra, ou seja, nasce antes da regra e não depois, como muitos o compreendem, em especial os adeptos da chamada pamprincipiologia ${ }^{68}$.

Nesse contexto, resta demonstrado o quão relevante é a compreensão dos fundamentos estatais e paradigmáticos de problemas envolvendo a própria concepção do processo e da jurisdição e, em especial, do estado democrático de direito e seus princípios. Quando obedecidos os ditames constitucionais e principiológicos, pelos quais foram constituídos os regramentos inerentes ao processo e à jurisdição, mesmo cientes da complexidade estrutural que lhes é peculiar, mostram-se, eles, como potentes e importantes instrumentos, tanto para a resolução de conflitos, como para a implementação de políticas públicas ${ }^{69}$, pois, ao

67 ROSA, Alexandre Morais da. Garantismo Jurídico e Controle de Constitucionalidade Material. Rio de Janeiro: Lúmen Juris, 2005. p. 3.

68 Sobre isso, ver: STRECK, Lenio. Do pamprincipiologismo à concepção hipossuficiente de princípio Dilemas da crise do direito. Revista de Informação Legislativa, Brasília, a. 49 n. 194 abr./jun. 2012.

69 DAMASKA, Mirjan R. Las Caras de la Justicia y el Poder del Estado. Análisis comparado del Proceso Legal. Santiago: Editorial Juridica del Chile, 1986, p. 28. 
fazê-lo, estarão garantindo constitucionalmente a sua efetiva concretização de direitos.

Pelo exarado até o momento, demonstra-se que, tanto pela perspectiva das transformações, quanto pelas perspectivas evolutivas emergidas pelo novo paradigma da complexidade, evidencia-se que a ciência processual busca a necessária efetividade normativa, ou seja, uma aplicação dos institutos processuais de acordo com princípios e regras constitucionais, para garantir os reais objetivos: a efetiva concretização dos direitos fundamentais.

Partindo da ideia de garantia do direito de defesa, com base no axioma nulla probatio sine defensione, faz-se imprescindível a atuação de uma defesa técnica frente à acusação, que sempre atua de forma, também, técnica, no sentido de restabelecer a igualdade das partes, quanto à capacidade e, para elevar à condição de igualdade inerente à posição de desvantagem, pela inferioridade do imputado/acusado ${ }^{70}$. Nesse sentido, o princípio basilar que fundamenta as regras processuais e, em especial, as inerentes aos atos probatórios é o contraditório.

No período da inquisição, a atuação da defesa foi dizimada a meras formalidades, por ser considerada impeditiva da atuação da justiça, causadora de confusão processual, tanto que foi adjetivada como uma arte baixa de intrigas ${ }^{71}$. Os direitos de defesa foram quase inutilizados em toda a fase de instrução, que tornou a ser inquisitória, notadamente, entregue à iniciativa do juiz, escrita, secreta, despida de contraditório e inteiramente controlada pelo órgão acusador, que se confundia com o julgador. A defesa foi excluída, até mesmo da fase do interrogatório, sendo possível a comunicação entre ambos (acusado e defesa), apenas, após o interrogatório e para acompanhar diligências ${ }^{72}$.

Para um controle da observância das garantias processuais é necessário o estabelecimento do contraditório como verdadeiro garantidor das respectivas garantias processuais. ${ }^{73}$ Para tanto, so-

\footnotetext{
70 FERRAJOLI, Luigi. Direito e Razão: Teoria do Garantismo Penal. São Paulo: RT, 2002. p. 490-491.

71 Ibidem, p. 491.

72 Ibidem, idem.

73 Ibidem, p. 492.
} 
mente haverá satisfação das respectivas garantias processuais, quando, toda e qualquer produção probatória que tenha por finalidade comprovar uma hipótese acusatória, for desenvolvida e sustentada publicamente ${ }^{74}$, de forma oral ${ }^{75}$ e mediante o rito processual previamente estabelecido.

Tudo que foi exposto e discutido até o momento, somente alcançará relevo conforme a proposta adotada, garantindo-se uma audiência oral, decorrente da publicidade e oralidade, como centro do processo. Ou seja, toda e qualquer afirmação acusatória somente será legítima, quando formalizada publicamente, de forma oral, perante o juiz competente, que terá, como principal etapa procedimental, o contraditório como garantidor das garantias, sendo que o exercício do contraditório não pode reduzir-se à possibilidade de falar apenas sobre o que se põe ao processo, deve ir além, implicando no poder e na capacidade de influenciar a decisão judicial e, para que esse direito seja efetivo, faz-se necessário o acesso à informação e força no confronto, pela disposição em paridade de $\operatorname{armas}^{76}$.

Concretamente, é preciso que o direito ao contraditório abranja: (1) a oportunidade de postular a prova em igualdade de condições; (2) a possibilidade de se pronunciar sobre a admissão das provas requeridas, antes da decisão sobre os pedidos; (3) a participação e assistência na produção da prova, incluindo, a presença pessoal e defesa técnica em todos os atos; (4) a possibilidade de aportar considerações sobre a validade do elemento probatório gerado pela produção, bem como as razões para sua valoração, antes que se convertam em resultados probatórios ${ }^{77}$.

74 Ibidem, idem.

75 Sobre isso: GONZÁLEZ POSTIGO, Leonel. La oralidad en la etapa recursiva del proceso penal chileno. Las audiencias ante la Corte de Apelaciones de Santiago. Revista Derecho Penal, ano III, n. 07, p. 333-374, mai. 2014.

76 ROSA, Alexandre Morais da; KHALED JÚNIOR, Salah H. Neopenalismo e Constrangimentos Democráticos. Florianópolis: Empório do Direito, 2015. p. 29.

77 SANTORO, Antônio Eduardo Ramires; RANGEL, Natália Ribeiro. O Princípio Constitucional do Contraditório na Interceptação das Comunicações Telefônicas. In: MENDES, Soraia da Rosa; LONGO, Ana Carolina F. (orgs.). Segurança Pública. Brasília: IDP, 2015. p. 7-34. 


\section{O Contraditório [DESDE que público e oral] como Significante ESTRUTURANTE DE UM NOVO MODELO DE SISTEMA PROCESSUAL PENAL.}

O princípio do contraditório não pode permanecer no discurso abstrato, distanciando-se sua aplicação, em razão das funcionalidades punitivistas do sistema, provocando sua reinterpretação, a contrário sensu, para manutenção das estruturas de viabilização do exercício arbitrário do poder estatal de punir. Em outras palavras, não se pode adaptar o princípio do contraditório à regulamentação legal do exercício do poder desmedido, para satisfação de um conjunto de expectativas criado ou manipulado que busca uma resposta punitiva.

Neste sentido, têm-se três premissas, onde as duas primeiras garantem a efetivação da terceira: a da informação [publicidade], na medida em que aos atores do jogo processual penal seja possibilitado exercer, de maneira consciente, suas posições, tendo-se ciência daquilo que se encontra na dinâmica dos acontecimentos e, ainda, e, não menos importante, a da plena condição de conhecimento (oralidade), para que não seja postergado ou burocratizado o ato de reação com possibilidade de refutação do que foi dito (contraditório) ${ }^{78}$. Este último revela a efetiva possibilidade de enfrentar o conjunto carreado no feito, de modo a não manifestar apenas uma atitude meramente contemplativa e pacífica dos acontecimentos, e, sim, possibilitar um atuar efetivo, em condições de influenciar diretamente na decisão a ser tomada pelo Estado-juiz. É imperiosa a compreensão de que a participação superficial das partes no processo, por si só, não concretiza o contraditório, pelo contrário, manipula uma percepção de contraditório falaciosa ${ }^{79}$.

A exteriorização do princípio do contraditório, na proposta de Fazzalari ${ }^{80}$, se dá em dois momentos. Primeiro com a informazione, consistente no dever de informação para que possam ser exercidas as

78 ROSA, Alexandre Morais da; SILVEIRA FILHO, Sylvio Lourenço da. Para um processo penal democrático: crítica à metástase do sistema de controle social. Rio de Janeiro: Lúmen Juris, 2008, p. 76-77.

79 Sobre isso, ver: BUONICORE, Bruno Tadeu; FELIZ, Yuri. Contraditório e Velocidade. Desafios do processo Penal Democrático na Sociedade Complexa. Revista dos Tribunais, vol. 945, p. 261-274, jul. 2014.

80 Sobre isso: FAZZALARI, Elio. Istituzioni di diritto processuale. Padova: Cedam, 1992. 
posições jurídicas, em face das normas processuais e, em um segundo momento, com a reazione, manifestada pela possibilidade de movimento processual, sem que este se constitua, todavia, uma obrigação ${ }^{81}$, por isso o dever/ser do contraditório vai além das aparências, da formalidade (condições ideais de fala e oitiva de ambas as partes), para se consubstanciar em poder de informação, força de confronto e paridade de armas.

Assim sendo, a lógica adotada é de que o poder nasce da informação (na dita busca pela verdade), porém, ainda que exista igual acesso às informações (respeitando o primeiro momento descrito por Fazzalari), não haverá contraditório sem a manifesta possibilidade de reação imediata do indivíduo (violando o segundo momento), prejudicando esse poder de resistência à pretensão acusatória, pela quebra na paridade de armas e pela ausência de oportunidade de resposta, na mesma intensidade e extensão. Em outras palavras, o contraditório exigiria a garantia de participação em simétrica paridade, onde todos esses fatores que compõem a substância do contraditório devem ser respeitados para sua efetivação ${ }^{82}$.

Para se falar sobre o contraditório deve-se partir da ideia de que se trata de uma garantia política, que deve habitar o cerne do processo penal, ao lado da ampla defesa ${ }^{83}$, sendo certo que sua ausência ou qualquer restrição de seu pleno exercício descaracteriza e macula, de maneira irreversível, a essência do sistema processual constitucional democrático ${ }^{84}$. Deste modo, um processo em que se amesquinha a possibilidade de informação ou reação, se vê gravemente ferido em sua própria existência, não podendo, em hipótese alguma, ser considerado como democrático ${ }^{85}$.

81 ROSA, Alexandre Morais da. Decisão Penal. A bricolage de significantes. Rio de Janeiro: Lúmen Juris, 2006. p. 264.

82 SANTORO, Antônio Eduardo Ramires; RANGEL, Natália Ribeiro. O Princípio Constitucional do Contraditório na Interceptação das Comunicações Telefônicas. In: MENDES, Soraia da Rosa; LONGO, Ana Carolina F. (orgs.). Segurança Pública. Brasília: IDP, 2015. p. 16

83 BINDER, Alberto M. Análisis político criminal: bases metodológicas para una política criminal minimalista y democrática. Buenos Aires: Astrea, 2011. p. 34.

84 ROSA, Alexandre Morais da; SILVEIRA FILHO, Sylvio Lourenço da. Para um processo penal democrático: crítica à metástase do sistema de controle social. Rio de Janeiro: Lúmen Juris, 2008. p. 90.

85 Ibidem, p. 92. 
A necessidade de compreensão do contraditório, como garantia política, transcende a esfera processual para ser elevado ao nível máximo de respeito e observação de suas premissas e contornos, visto que basta se observar que todos os objetivos e teorias inerentes à pena foram e ainda estão sendo transportados para o uso das prisões cautelares, logo, os anseios criados no uso das respectivas prisões são os mesmos depositados no resultado final do processo ${ }^{86}$. Ou seja, cria-se uma ânsia de punição rápida, no curso de uma investigação ou processo, sob alegação de demora no trâmite processual e necessidade de uma resposta desmedida, que satisfaça as pretensões/ambições dos governados, predominantemente formados por minoria, não desviante, garantindo uma pseudo segurança social ${ }^{87}$. Daí importância vital do reconhecimento e respeito ao contraditório.

O pressuposto da pena deve ser a comissão de um fato univocamente descrito e indicado como delito e, não apenas pela lei, mas, também, pela hipótese de acusação, de modo que resulte suscetível de prova e de confrontação judicial. Essa que é a decorrência lógica de uma alegação feita e, imediatamente, contraposta pela parte acusada. A necessidade de sujeição das hipóteses acusatórias à verificação e possibilidade de refutação, permite que o juiz, no exercício do poder jurisdicional, possa basear sua decisão no controle empírico, evitando assim a aceitação de uma verdade ou argumento evidente por si, dispensando provas para ser compreendido e aceito ${ }^{88}$.

Mesmo identificando uma heterogeneidade de pressupostos filosóficos, geradores de inúmeros princípios que compõem o modelo penal e processual, que, de forma epistemológica, servem de instrumentos de contenção do exercício arbitrário do poder, os quais, uma vez desrespeitados, levam à ilegitimidade do ato jurisdicional praticado. Tendo como objeto de análise, o princípio do contraditório, da defesa, da falseabilidade ou, como define Ferrajoli, nulla probatio sine defensione ${ }^{89}$.

\footnotetext{
86 FERRAJOLI, Luigi. Direito e Razão: Teoria do Garantismo Penal. São Paulo: RT, 2002. p. 444.

87 Ibidem, p. 210-211.

88 Ibidem, p. 32.

89 Ibidem, p. 75
} 
Deixando de lado o pessimismo pela ideia de impossibilidade satisfativa plena de seus postulados, seja no âmbito da prova e da defesa, verificação e refutação, entre abstrato [lei] e concreto [hipótese acusatória], para se buscar o máximo grau de racionalidade e confiabilidade do ato jurisdicional e, consequente limitação ao exercício do poder arbitrário em respeito à tutela individual.

De nada adiantará uma Constituição e legislação penal que tenham como finalidade a garantia dos direitos individuais, se não estiverem acompanhadas de um conjunto de garantias processuais, as quais possam expressar recíproca efetividade desses direitos, seja assegurando-lhes seu respeito ou considerando ilegais os atos que os violem. A presunção de inocência, como forma de tratamento a ser destinada para todos investigados e acusados, traz consigo, não só uma forma de tratamento, como também a definição do ônus da prova a cargo da acusação. O direito de defesa que será aplicado em sua plenitude, através do princípio do contraditório.

No entanto, toda essa compreensão de democracia constitucional e o protagonismo dos princípios constitucionais, deve estar acompanhada de uma efetiva regulamentação da forma como o exercício do poder jurisdicional será exercício. Logo, falar de procedimento e processo na perspectiva trabalhada por Elio Fazzalari ${ }^{90}$ e Aroldo Plínio Gonçalves ${ }^{11}$, é buscar alternativas para a efetivação dos direitos e garantias a serem protegidos e implementados, evitando-se, assim, o arvoramento inquisitivo, que assombra a legislação infraconstitucional.

Ao tomar a noção de procedimento como gênero, que abarca toda estrutura procedimental, visto como um conjunto de atos e posições subjetivas dirigidas a um provimento final ${ }^{92}$, e o processo como um procedimento que se realiza pelo contraditório, este entendido como garantia de construção participada da decisão, contribui-se significati-

90 Sobre isso, ver: FAZZALARI, Elio. Istituzioni di diritto processuale. Padova: Cedam, 1992.

91 Sobre isso, ver: GONÇALVES, Aroldo Plínio. Técnica processual e teoria do processo. Rio de Janeiro: Aide, 1992.

92 FAZZALARI, Elio. Istituzioni di diritto processuale. Padova: Cedam, 1992. p. 861 
vamente para a efetivação da garantia procedimental e sua essência ${ }^{93}$, na busca pela concretização do princípio do contraditório, deslocando-o para o eixo que fundamenta todo o sistema processual.

Nesse sentido, é permitido afirmar que, embora prevaleça a decisão do julgador, os destinatários da decisão proferida (acusação e defesa) devem participar de sua construção, com paridade de armas e sob o crivo do contraditório, que será efetivado, desde que mediante ato público e oral $^{94}$. Esse contexto permite viabilizar um verdadeiro jogo democrático, em cujo bojo a forma procedimental adotada permite a provocação, viabilização e interferência direta na decisão judicial pela parte almejada.

Com efeito, compreender o contraditório, não mais como um mero garantidor da simétrica paridade de armas entre os sujeitos interessados, mas, também, como verdadeira garantia de influência na decisão a ser tomada como resultado do processo, é um dos pilares estruturantes do princípio do contraditório.

A afirmação de que a respectiva audiência deve ser um procedimento, que necessita ser realizado em contraditório, amparado numa estrutura constitucionalizada do processo, é legitimada, ainda, pela máxima efetivação dos direitos e garantias individuais, a serem protegidos pelo próprio Estado, quando no exercício do seu poder. O discurso de legitimação democrática do Direito exige a institucionalização de um processo político de cidadãos para que se reconheçam mutuamente como titulares de direitos humanos fundamentais ${ }^{95}$. Um processo efetivamente democrático.

93 BARROS, Flaviane de Magalhães. O modelo constitucional de processo e o processo penal: a necessidade de uma interpretação das reformas do processo penal a partir da Constituição. In: AMORIM MACHADO, Felipe Daniel; CATTONI OLIVEIRA, Marcelo Andrade (Coords.). Constituição e Processo: A contribuição do processo ao constitucionalismo democrático brasileiro. Belo Horizonte: Del Rey, 2009, p. 333.

94 "[...] fenômeno da participação dos interessados no iter de formação dos provimentos (entendendo-se como tais, aqueles em cuja esfera o ato é destinado a incidir) - mais precisamente, o fenômeno da participação dos interessados na fase de reconhecimento dos pressupostos do provimento" (FAZZALARI, Elio. Istituzioni di diritto processuale. Padova: Cedam, 1992. p. 861) (tradução livre).

95 HABERMAS, Jürgen. Direito e democracia: entre faticidade e validade. Trad. Flávio Beno Siebeneicheler. Rio de Janeiro: Tempo Brasileiro, 1998. p. 113-160. 
Essa legitimação invocada para a procedimentalização, em contraditório [exemplo, na audiência de custódia], parte da ideia de racionalidade teórica, na qual, ao contrário de outras teorias, Habermas fornece, em face do paradigma do Estado Democrático do Direito, apoio técnico, imprescindível ao ingresso e problematização de importantes aspectos do direito processual constitucionalizado ${ }^{96}$. Isso porque a teoria procedimentalista da democracia, proposta pelo autor passa por uma [re] leitura de importantes aspectos de legitimidade do direito não tangidas pelas demais abordagens ${ }^{97}$. Percebe-se que toda sentença é constitutiva de efeitos processuais e não de direito material.

Mas por que um procedimento em contraditório? A concepção de que o processo seria uma espécie de procedimento, caracterizado pela presença do contraditório, não nega ser um conjunto de atos, até porque, se contém procedimento, é mesmo inafastável. Ocorre que esse processo, como um procedimento desenvolvido com participação dos interessados, destina-se a um fim específico, qual seja a prolação de uma decisão pelo juiz, no entanto, imperioso que essa decisão, para ser legítima, deva ser resultado da atuação das partes de forma dialética na ordem estabelecida pela lei.

Essa imagem de um novo conceito de procedimento e de processo tornou possível a compreensão de que, entre procedimento e processo não há distinção, e sim, uma relação de inclusão, uma vez que o processo é uma espécie do procedimento e dele se distingue por uma propriedade particular que é o contraditório. O procedimento torna-se parte essencial do processo ${ }^{98}$. Este traço distintivo entre os dois não se limita a pensar num conceito amplo de um e outro, entendendo ser o processo uma espécie do procedimento, desenvolvido com a participação dialética das partes destinatárias da decisão final, ou seja, o processo

96 HABERMAS, Jürgen. Teoría de la acción comunicativa I: racionalidad de la acción y racionalización social. Trad. Manuel J. Redondo. Madrid: Taurus, 1987. p. 15-26.

97 LEAL, André Cordeiro. O contraditório e a fundamentação das decisões. Belo Horizonte: Mandamentos, 2002. p. 153.

98 GONÇALVES, Aroldo Plínio. Técnica processual e teoria do processo. Rio de Janeiro: Aide, 1992. p. 68. 
se caracteriza por uma característica reitora do procedimento, caso contrário, haverá procedimento sem processo.

Portanto, o procedimento distingue-se do processo pela ausência da qualidade indissociável daquele, que é o contraditório, devendo merecer estudo especial para defini-lo, não mais como a ritualística manifestação perceptível do processo, mas como uma estrutura técnica de atos jurídicos praticados por sujeitos de direito, que se configuram pela sequência obediente à conexão de normas procedimentais preexistentes. É a estrutura extraída do texto normativo, que a ela é preexistente e que lhe confere legitimidade, validade e eficácia, pelo princípio da reserva legal. Por óbvio, o procedimento não se concretiza pela lógica diretiva da atividade jurisdicional do juiz, mas pelas condicionantes lógicas dos princípios e institutos do processo constitucional democrático, nas quais as partes integrantes do processo influenciam diretamente na decisão final, a ser tomada pelo juiz no exercício do poder jurisdicional ${ }^{99}$.

\section{Considerações Finais}

Importante compreender que o procedimento, em abstrato, como sequência de atos, tem compromisso com os fins da jurisdição e com os direitos dos cidadãos, ou seja, o processo e o procedimento não só servem ao exercício da jurisdição pelo Estado, de modo a proteger os direitos fundamentais do indivíduo, mas, também, são legítimos porque permitem o exercício do poder jurisdicional de maneira democrática, assegurando o contraditório e respeitando os preceitos democráticos insculpidos na Constituição de 1988.

Tendo em vista o sentido político, o juízo oral adquire um protagonismo de centralidade do processo, por conta de que, a todo momento, o investigado ou o acusado terá o direito de influenciar diretamente na decisão a ser tomada pelo juiz, principalmente nos casos em que a respectiva decisão puder afetar diretamente a liberdade do indivíduo. A implementação do contraditório oral, mediante uma atuação dialética

99 LEAL, Rosemiro Pereira. Teoria geral do processo: primeiros estudos. 7. ed. Rio de Janeiro: Forense, 2008, p. 94. 
entre defesa técnica e acusação, para pedido de imposição de prisão preventiva ou mesmo de medidas diversas, seja na fase pré-processual ou durante a instrução, protege não só os direitos individualizados, como garantem uma influência e controle direto na decisão a ser proferida, fortalecendo toda a estrutura jurisdicional no exercício do poder.

Maior dificuldade encontra-se na contracultura jurídica que se vive, pois existe um apego ao formalismo escrito, que acaba por constituir um verdadeiro obstáculo na implementação de mudanças. Óbvio que a história acaba por modelar todos os processos e, também, o próprio desenvolvimento dos sistemas judiciais, no entanto, conforme aqui trabalhado, deve-se prezar pela observação de todos os direitos e garantias previstos na constituição, mesmo que em detrimento de tradições práticas as quais tentam impedir a evolução jurídica.

O contraditório compreende a própria definição de processo e significa o espaço argumentativo em que às partes, em igualdade de condições, perante um procedimento público e oral, será garantida a participação na construção da decisão, onde o juiz, no exercício do poder jurisdicional, deverá, necessariamente, construir a respectiva decisão com base em uma fundamentação que utilize os argumentos das respectivas partes [autor e réu], participantes do debate, através de ampla argumentação como garantia necessária para a efetiva construção de argumentos.

$\mathrm{Na}$ busca por conferir concretude ao entendimento de que o contraditório, por ser uma garantia política, tratado como uma das características do sistema democrático para conferir exercício pleno de seus objetivos políticos e processuais, pode-se desmembrar em quatro momentos processuais que devem ser respeitados em nome da efetivação desse princípio, quais sejam: (1) oportunidade de postular a prova em igualdade de oportunidades e condições do órgão acusador quanto à hipótese acusatória levantada; (2) possibilidade de impugnar a decisão, que admite a prova produzida pela parte contrária; (3) participação e assistência na produção da prova; e (4) o controle da racionalidade da decisão do julgador pela impugnação dos fundamentos apresentados, através da via recursal própria.

Se, porventura, advir uma decisão fundamentada em argumentos não-jurídicos ou em argumentos não utilizados pelas partes, ocorre 
a violação do princípio do contraditório, núcleo estruturante e reitor do processo penal, visto que as partes não participaram da construção da respectiva decisão proferida.

Logo, somente diante de um procedimento público e oral [princípios que constituem uma base principiológica uníssona e indissociável], será possível impor limites e controle ao exercício do poder jurisdicional, para então, se for o caso, impugnar uma decisão que tenha desrespeitado o princípio do contraditório. Se esses princípios [garantias do processo] foram respeitados, a decisão é aceitável por ser racional e legítima. Essa conexão demonstra que se houver supressão do contraditório, haverá a violação dos demais princípios, pois a decisão foi construída somente pelo juiz, fundamentada por argumentos desse único intérprete (solipsismo judicial).

\section{REFERÊNCIAS}

ADEODATO, João Maurício. Jurisdição constitucional à brasileira - situações e limites. Revista do Instituto de Hermenêutica Jurídica. V.1. n. 2. Porto Alegre, 2004.

AROCA, Juan Montero. El derecho procesal en el Siglo XX. Valencia: Tirant lo Blanch, 1997.

BARATTA. Alessandro. Criminologia Crítica e Crítica ao Direito Penal. Introdução à sociologia do Direito Penal. Rio de Janeiro: Revan, 2011.

BARROS, Flaviane de Magalhães. O modelo constitucional de processo e o processo penal: a necessidade de uma interpretação das reformas do processo penal a partir da Constituição. In: AMORIM MACHADO, Felipe Daniel; CATTONI OLIVEIRA, Marcelo Andrade (Coords.). Constituição e Processo: A contribuição do processo ao constitucionalismo democrático brasileiro. Belo Horizonte: Del Rey, 2009.

BUONICORE, Bruno Tadeu; FELIZ, Yuri. Contraditório e Velocidade. Desafios do processo Penal Democrático na Sociedade Complexa. Revista dos Tribunais. vol. 945, p. 261-274, jul. 2014.

BINDER, Alberto M. Introdução ao direito processual penal. Rio de Janeiro: Lúmen Juris: 2003.

BINDER, Alberto M. Análisis político criminal: bases metodológicas para una política criminal minimalista y democrática. Buenos Aires: Astrea, 2011. 
DAMASKA, Mirjan R. Las Caras de la Justicia y el Poder del Estado. Análisis comparado del Proceso Legal. Santiago: Editorial Juridica del Chile, 1986.

CASARA, Rubens. R. R. Interpretação Retrospectiva, Constituição e Processo Penal. Revista da EMERJ, v. 6, n. 22, 2003.

CATTONI DE OLIVEIRA, M. A. Comentário ao Art. 1. ${ }^{\circ}$, parágrafo único. In: CANOTILHO, J. J. G.; MENDES, G. F.; SARLET, I. W.; STRECK, L. L. (coord.) Comentários à Constituição do Brasil. São Paulo: Saraiva, 2013.

CUNHA JR., Dirley da Cunha. Curso de Direito Constitucional. 2. ed. Salvador: JUSPODIVM, 2016.

DAMASKA, Mirjan R. Las Caras de la Justicia y el Poder del Estado. Análisis comparado del Proceso Legal. Santiago: Editorial Juridica del Chile, 1986.

FAZZALARI, Elio. Istituzioni di diritto processuale. Padova: Cedam, 1992.

FERRAJOLI, Luigi. Direito e Razão: Teoria do Garantismo Penal. São Paulo: RT, 2002.

FERRAJOLI, Luigi. Principia Iuris. Teoria del diritto e della democrazia. 2. Teoria della democrazia. Roma-Bari: Laterza, 2007.

FERRI, Enrico. Princípios do Direito Criminal: o criminoso e o crime. 2. ed. Tradução: Paolo Capitanio. Campinas: Bookseller, 1998.

FREUD, Sigmund. Totem e Tabu. Algumas correspondências entre a vida psíquica dos selvagens e a dos neuróticos. Tradução do alemão de Renato Zwick. Porto Alegre: L\&PM POCKET, 2013.

GAROFALO, Raffaele, CARELLI, L. Riforma Della Procedura Penale In Italia. Torino: Fratelli Bocca Editori, 1889.

GONÇALVES, Aroldo Plínio. Técnica processual e teoria do processo. Rio de Janeiro: Aide, 1992.

GONZÁLEZ POSTIGO, Leonel. La oralidad en la etapa recursiva del proceso penal chileno. Las audiencias ante la Corte de Apelaciones de Santiago. Revista Derecho Penal, ano III, n. 07, p. 333-374, mai. 2014.

HABERMAS, Jürgen. Direito e democracia: entre faticidade e validade. Trad. Flávio Beno Siebeneicheler. Rio de Janeiro: Tempo Brasileiro, 1998.

HABERMAS, Jürgen. Teoría de la acción comunicativa I: racionalidad de la acción y racionalización social. Trad. Manuel J. Redondo. Madrid: Taurus, 1987.

LEAL, André Cordeiro. O contraditório e a fundamentação das decisões. Belo Horizonte: Mandamentos, 2002.

LEAL, André Cordeiro. Teoria geral do processo: primeiros estudos. 7. ed. Rio de Janeiro: Forense, 2008. 
LEAL, Rosemiro Pereira. Teoria Processual da Decisão Jurídica. São Paulo: Editora Landy, 2002.

LÉVI-STRAUSS, Claude. Antropologia Estrutural Dois. 4a ed. Rio de Janeiro: Tempo Brasileiro, 1993.

LOPES Jr., Aury. O Novo Regime Jurídico da Prisão Processual, Liberdade Provisória e Medidas Cautelares Diversas. 2. ed. Rio de Janeiro: Lumen Juris, 2011.

MARTINS, Rui Cunha. O Ponto Cego do Direito. Rio de Janeiro: Lúmen Juris, 2010 .

MIRANDA COUTINHO, Jacinto Nelson de. As reformas parciais do CPP e a Gestão da Prova: Segue o Principio Inquisitivo. Boletim do IBCCRIM, ano 16, $\mathrm{n}^{\mathrm{o}}$ 188, p. 11-13.

NETO, Alfredo Copetti. A Democracia Constitucional sob o olhar do garantismo jurídico. Florianópolis: Empório do Direito, 2016.

MIRANDA COUTINHO, Jacinto Nelson de. Introdução aos princípios gerais do processo penal brasileiro. Revista da Faculdade de Direito da UFPR, a. 30, n. 30, 1998.

NICOLITT, André Luiz. Lei 12.403/2011: o novo processo penal cautelar, a prisão e as demais medidas cautelares. 2. ed. Rio de Janeiro: Elsevier, 2016.

NUNES, Dierle José Coelho. O princípio do contraditório. Boletim Técnico da Escola Superior de Advocacia da OAB/MG, Belo Horizonte, v.1, p. 39-55. jan./ jun. 2004.

PRADO, Geraldo. Prova Penal e sistemas de controles epistêmicos. A quebra da cadeia de custódia das provas obtidas por métodos ocultos. São Paulo: Marcial Pons, 2014.

PRADO, Geraldo; CASTANHO DE CARVALHO, L. G Grandinetti; MARTINS, Rui Cunha. Decisão Judicial. A cultura jurídica brasileira na transição para a democracia. São Paulo: Marcial Pons, 2012.

PILATTI, Adriano. A Constituinte de 1987-1988. Progressistas, Conservadores, Ordem Econômica e Regras do Jogo. Rio de Janeiro: Lumen Juris, 2008.

ROSA, Alexandre Morais da. Decisão Penal. A bricolage de significantes. Rio de Janeiro: Lúmen Juris, 2006.

ROSA, Alexandre Morais da. Garantismo Jurídico e Controle de Constitucionalidade Material. Rio de Janeiro: Lúmen Juris, 2005.

ROSA, Alexandre Morais da; SILVEIRA FILHO, Sylvio Lourenço da. Para um processo penal democrático: crítica à metástase do sistema de controle social. Rio de Janeiro: Lúmen Juris, 2008. 
ROSA, Alexandre Morais da; KHALED JÚNIOR, Salah H. Neopenalismo e Constrangimentos Democráticos. Florianópolis: Empório do Direito, 2015.

ROXIN, Claus. Pasado, Presente y Futuro del Derecho Procesal Penal. Buenos Aires: Culzoni Editores, 2004.

SABADELL, Ana Lucia. Manual de sociologia jurídica: introdução a uma leitura externa do Direito. São Paulo: RT, 2003.

SANTORO, Antônio Eduardo Ramires; RANGEL, Natália Ribeiro. O Princípio Constitucional do Contraditório na Interceptação das Comunicações Telefônicas. In: MENDES, Soraia da Rosa; LONGO, Ana Carolina F. (orgs.). Segurança Pública. Brasília: IDP, 2015.

SANTOS, Bartira Macedo de Miranda. Lombroso no Direito Penal: o destino d'O Homem Delinquente e os perigos de uma ciência sem consciência. Disponível em: <http://www.publicadireito.com.br/artigos/?cod=ea6b2efbdd4255a9>. Acesso em: 01 mar. 2017.

STRECK. Lenio. Do pamprincipiologismo à concepção hipossuficiente de princípio. Dilemas da crise do direito. Revista de Informação Legislativa, Brasília, a. 49 n. 194 abr./jun. 2012.

UNODC/CEJA (2013). La reforma procesal penal en Latinoamérica. In: Evalución de la implementación del sistema penal acusatório en Panamá, p. 07-12. Disponível em: <http://biblioteca.cejamericas.org/handle/2015/5493>. Acesso em: 07 dez. 2016.

\section{Informações adicionais e declarações dos autores (integridade científica)}

Declaração de conflito de interesses (conflict of interest declaration): o autor confirma que não há conflitos de interesse na realização das pesquisas expostas e na redação deste artigo.

Declaração de coautoria e especificação das contribuições (declaration of authorship): todas e somente as pessoas que atendem os requisitos de autoria deste artigo estão listadas como autores.

Declaração de ineditismo e originalidade (declaration of originality): o autor assegura que o texto aqui publicado não foi divulgado anteriormente em outro meio e que futura republicação somente se realizará com a indicação expressa da referência desta publicação original; também se atesta que não há plágio de terceiros ou autoplágio. 
Dados do processo editorial

(http://www.ibraspp.com.br/revista/index.php/RBDPP/about/editorialPolicies)

- Recebido em: 24/06/2017

- Controle preliminar e verificação de plágio: 27/06/2017

- Avaliação 1: 11/07/2017

- Avaliação 2: 11/07/2017

- Avaliação 3: 18/07/2017

- Decisão editorial preliminar: 25/07/2017

- Retorno rodada de correções 1: 08/08/2017

- Decisão editorial preliminar 2: 15/08/2017

- Retorno rodada de correções 2: 31/08/2017

- Decisão editorial preliminar 3: 01/09/2017

- Retorno rodada de correções 3: 03/09/2017

- Decisão editorial final: 03/09/2017

\section{Equipe editorial envolvida}

- Editor-chefe: 1 (VGV)

- Editora-associada: 1 (FMB)

- Editor-assistente: 1 (CRG)

- Revisores: 3

\section{COMO CITAR ESTE ARTIGO:}

MINAGÉ, Thiago M. A. Contraditório público e oral como garantidor de um processo penal democrático constitucional. Revista Brasileira de Direito Processual Penal, Porto Alegre, vol. 3, n. 3, p. 929-964, set./dez. 2017. https://doi.org/10.22197/rbdpp.v3i3.85

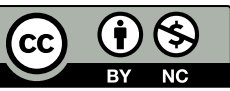

Esta obra está licenciada com uma Licença Creative Commons Atribuição-NãoComercial 4.0 Internacional. 